\title{
VERSHINA - A POLISH VILLAGE IN SIBERIA. FACTORS INFLUENCING LANGUAGE MAINTENANCE UNDER CHANGING SOCIAL, CULTURAL, ECONOMIC AND POLITICAL CONDITIONS
}

\author{
Michał Głuszkowski \\ Nicolaus Copernicus University in Toruń
}

\begin{abstract}
The article discusses factors influencing language maintenance under changing social, cultural, economic and political conditions of Polish minority in Siberia. The village of Vershina was founded in 1910 by Polish voluntary settlers from Little Poland. During its first three decades Vershina preserved Polish language, traditions, farming methods and machines and also the Roman Catholic religion. The changes came to a village in taiga in the 1930s. Vershina lost its ethnocultural homogeneity because of Russian and Buryat workers in the local kolkhoz. Nowadays the inhabitants of Vershina regained their minority rights: religious, educational and cultural. However, during the years of sovietization and ateization, their culture and customs became much more similar to other Siberian villages. Polish language in Vershina is under strong influence of Russian, which is the language of education, administration, and surrounding villages. Children from Polish-Russian families become monolingual and use Polish very rare, only as a school subject and in contacts with grandparents. The process of abandoning mother tongue in Vershina is growing rapidly. However, there are some factors which may hinder the actual changes: the activity of local Polish organisations and Roman Catholic parish as well as folk group "Jazhumbek".
\end{abstract}

Keywords:, bilingualism, language maintenance, language death, Poles, Siberia

\section{History}

In Polish culture and historiography Siberia has been associated with exiled Poles. The tsarist authorities often sent their enemies and mutineers into penal colonies. However, Siberia has another face - it was also the land of space and new possibilities. The 
village of Vershina was founded in 1910 by Polish voluntary settlers from North-Eastern Silesia and Little Poland. People moved into Siberia (130 km from Irkutsk) because Peter Stolypin (Prime Minister of Russia 1906-11) had guaranteed them a 16 ha parcel, free building materials, subsidies of 100 roubles, $75 \%$ of travel costs and lower taxes for several years (Петшик 2008: 7-8). Stolypin planned to colonise uninhabited Russian territories and the residents of Southern Poland followed his ideas because of the economic crisis in their region in the beginning of the 20th century (Bazylow 1975: 169-170). In Vershina's history we can divide three main periods with a special language situation.

\section{The pre-war period (1910-1940)}

First years in a new place were extremely difficult to survive. The migrants had to live in dugouts until they built their houses and it took several months to grub out and clear each parcel off stones Петшик 2008: 11-12). During its first three decades Vershina represented a piece of Poland in the heart of Siberia. The settlers spared no efforts to build a Roman Catholic church and a polish school even though most of them had not built their houses yet (Szostak 2002: 226-227). These facts show how important was religion and Polishness for the inhabitants of Vershina. The village preserved Polish language, traditions, farming methods, machines and also the Roman Catholic religion. Polish settlers easily recognized their identity. They differed culturally, linguistically, religiously and also anthropomorphically from the native residents of Siberia - Buryats (Dybowski 2007: 244-246). These differences prevented heterogeneous marriages. The descendants of Ukrainian settlers from Tikhonovka, a village located 17 kilometres from Vershina were culturally much closer to the inhabitants of the Polish village, but also these two communities did not assimilate.

Polish was the only language spoken in contacts inside the village. Although the migrants knew Russian language, they used it practically only for contacts with administration and with Buryats from neighbouring village Dundai. This situation lasted till the early 1930s. Children were learning Russian as a foreign language at the local primary school in the years 1911-1916. After 1916 all subjects were taught in Russian, but at home and in everyday life everyone used Polish (Wiśniewska 2000: 102). The Revolution of 
1917 meant the end of the former Russia with its economic system, but the effects of changes came to distanced villages in taiga only after some years. The socio-economic structure of Vershina started to change when collectivisation begun. The inhabitants of Vershina did not want to lose their farms, which were the main reason of their migration. They worked hard and spent a lot of time to prepare their parcels for agriculture. It was not easy to collect all indispensable tools and machines and in the 1930s they were forced to join the kolkhoz. These who did not accept the orders of communist authorities were arrested and intimidated Петшик 2008: 14-15). Other measures of coercion were connected with confiscates of crops, cattle, pigs, horses and agricultural machines. The hardest repressions came in 1937, when 30 peasants were arrested and accused of hatching a plot against the Soviet authorities. After fixed trial they were shot in 1938 (Szostak 2002: 228-234). This was also the time when the church in Vershina has been closed and only thanks to the stance of some oldest people it was not completely destroyed. These events finally crushed the resistance against collectivization and begun the period of intense atheization. Few years later the village lost its former ethnocultural homogeneity because inhabitants from a small settlement of Odigon joined the Vershinian kolkhoz Петшик 2008: 19). The descendants of Polish migrants had to live and work together with Russian and Buryat workers. The following social and demographical changes were caused by the Second World War. Some men from Vershina were conscripted and never returned to their homes (they were killed or stayed in the regions were they fought). After the war Polish people in Vershina did not obey the former traditional rule of homogeneous marriages and married also Russians and Ukrainians, but there still were not marriages between Poles and Buryats.

\section{Primary socialization in the pre-war period}

One has to focus on the process of primary socialization and the role of primary groups in the pre-war period. Being a result of a child's embrace into cultural practices and norms, the primary socialization influences language acquisition (AdamovičiuteČekmonene 2003). According to P. Berger and T. Luckmann (1983: 204) this is the most important period of socialization, which takes place in primary groups, i.e. groups characterized by intimate face- 
to-face association and cooperation, such as family, neighbourhood and peer groups (Cooley 1992: 209). All of Vershina's inhabitants were speaking Polish and only in the stage of secondary socialization the descendants of migrants acquired Russian (at school and in contacts with state authorities). In the pre-war period it was natural to speak Polish at home, in the village-shop or at work in the kolkhoz. Even Buryats and Russians, who were living in Vershina, knew and spoke Polish.

The way of language acquisition entailed special formation of Vershinian bilingualism. Its specificity was connected with diglossia, although it was difficult to qualify any of the languages as a code of high or low prestige. According to Charles Ferguson's (1959: 336) definition, the 'high' language "is learned largely by formal education and is used for most written and formal spoken purposes" and the 'low' one - for ordinary conversation. This definition suggests that we consider Russian as 'high' code and Polish as 'low', but in the pre-war period this division did not correspond with both languages' prestige which was equal. Russian gained its prestige as the official language of the country, and Polish was the traditional language and practically the only mean of communication in the contacts inside the village. However, with the flow of time the language situation of Vershina, the prestige of its languages and domains of use were changing.

\section{Social changes in the post-war period (1941- 1989)}

First changes came in the post-war, communist period, which lasted half a century - till the late 1980s. Because of new workers in the local kolkhoz and heterogeneous marriages Vershina became multiethnic. Of course, the descendants of Polish settlers of 1910 were still in majority, but gradually there were more children from Polish-Russian families. According to E. Nowicka and M. GłowackaGrajper (2003: 45), Polish sociologists and anthropologists who investigated the identity of Vershinians, the mixed families tend to choose Russian identity. Being in minority they still were speaking Polish but the changes stepped up and embraced all aspects of life of the village. In the pre-war period the inhabitants of Vershina cultivated all the customs and traditions they remembered from their region of origin. The Roman Catholic religion was an impor- 
tant factor preserving their mother culture, e.g. the system of holidays depended on the church calendar. After the war the process of sovietization completely changed the calendar. All church holidays were forbidden and the authorities introduced new, communist red-letter days. The Vershinians remembered the most important church holidays such as Easter and Christmas, but all other holidays were soon forgotten (Figura 2003: 108-111). The popular ceremonies and customs, e.g. christening, engagement and burial were successively enriched with Russian, Soviet and Buryat elements. For example the young couple on their way from the civil registry office stops in holy Buryat places to sprinkle the soil with alcohol - a Buryat custom. After the funeral, people in Vershina eat a meal at the cemetery, drink vodka and pour a glass, and leave some food at the grave what was adopted from Russian culture. Nowadays we can describe Vershina's culture as a Polish-RussianSoviet-Buryat hybrid, because it consists of differentiated elements put into Polish framework. The changing traditions and customs influenced the process of socialization. Local primary groups in the 1960 or 1970s differed from the situation before the Second World War. Polish has been still the basic language in face-to-face domain, but the cultural border between young people from Vershina and their peers from neighbouring villages was no more strict.

\section{Language}

People, who founded Vershina, brought with them a mixture of local dialects from their place of origin (Гольцекер 1989). The dialects of Little Poland and North-Eastern Silesia were structurally not far from each other and nowadays it is a very difficult task to distinguish all components of Vershina's language. In the pre-war period contacts with Russian-language speaking population were limited and the Polish village constituted a language island, i.e., a territory isolated from its language motherland (Дуличенко 1998: 26). Because of the socio-political changes it was not possible to prevent Polish language in Vershina from strong influence of Russian, which was the language of education, administration, and also of some workers in the local kolkhoz. Young men from Vershina served in the Red Army as conscripts. The youth wanted to change their lives and leave the village without prospects. In the Soviet Union there was a rule forbidding the workers 
of kolkhozes to leave their place of residence. They had no identity cards and the only sure way to leave the village was marriage with an inhabitant of the town. It was another reason for mixed Polish-Russian marriages. Some young people managed to study in a secondary school or a high school in Irkutsk. According to their and their relatives' account young Vershinians often felt ashamed because of their origin and tried to hide their national identity (E. Nowicka and M. Głowacka-Grajper, p. 52). In Soviet Union it was not popular and also unsafe to be proud of Polishness. These are the reasons why the equilibrium of both languages prestige has been upset in the post-war period. The diminishing prestige of Polish language increased the total amount of interference in this code. Of course, Polish language in Vershina adopted Russian lexis and syntactic structures from its very beginning, but its high prestige and language loyalty of its users successfully prevented mass interference. The post-war period was the decisive time for language evolution.

\section{Interference}

Polish language in Vershina underwent strong Russian influence, but the grammatical system did not change much. Polish and Russiuan elements in Vershinians' speech are still easy to recognize. However, one has to admit that the discussion about preservation and maintenance of Polish language in frames of Polish Russian bilingualism refers not to the 'clean' or standard literary Polish, but to a mix of Southern-Polish dialects enriched with many foreign elements. According to I. Grek-Pabisowa (1999: 224-227) there are two kinds of borrowings: the non-adopted and the adopted ones. The non-adopted borrowings appear in the borrowing language unchanged, just as they function in the other language, with all its features. In the cited examples Russian words are underlined:

no kań'ešna i galar'etka, $i$ but'eck' $i$ ' and obviously there was jelly and buns' - Rus. конечно (obviously) instead of Pol. oczywiście;

pr'otiv Kość'oła 'one b'yty, pr'ot'iv všystk' ego 'they were against church, against everything' - Rus. против (against) instead of Pol. przeciwko;

\footnotetext{
The transcription used in this article is simplified Slavonic one.
} 

(no one);

$\underline{n i k t} \underline{\text { no }}$ tu ne exce być 'no one wants to be here' - Rus. никто

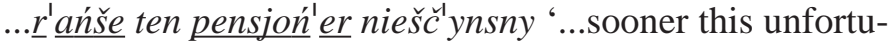
nate retiree' - Rus. раньше (sooner) and пенсионер (retiree) instead of Polish wcześniej and emeryt.

Adaptation is connected with substitution of phonemes, affixes and endings. It is considered as full if all these elements are replaced with their equivalents from the borrowing language. I. Grek-Pabisowa (1999: 224-225) classifies a word as partially adopted, when not all its phonemes are replaced.

tyx s'taryx l'uzi ine $\boldsymbol{o b}$ ' $i z^{\prime} \boldsymbol{i c}$ ' not to offend these old people' - Rus. обидить (offend) - phoneme substitution: $d$ ' replaced with $3^{\prime}$ and $t^{\prime}$ with c';

to to nastoj'aščo p'olsko śp' 'ivka 'this is a true Polish folk song' - Rus. настоямая (true) - Russian adjective feminine ending -aya replaced with Polish - $a$;

ja śe P'olkom sčytam 'I consider myself Polish' - Rus. cчumamb inf. (consider) - adaptation to Polish conjugation paradigm;

$v$ l'eśe tak s'amo v'ency oxotń'ikuv jak tam żicy jes 'so it is in the forest, there are more hunters than game' - Rus. охотник (hunter) - adaptation to Polish declension paradigm.

Russian influence on Vershinian dialect is visible not only as single elements, but also at the levels of morphology, word-formation, syntax and semantics, what is connected with loan translations. J. Obara (1989: 193-194) distinguished four main types of loan translations: semantic, derivational, phraseological and syntactical. He (1989: 200-201) classified words in the recipient-language which change their meaning or achieve additional sense under the influence of the other language, as the semantic loans. Semantic loans are relatively rare in the Vershinians' speech.

$w$ šk'ole to zastav'al'i naucyć'ele pacem'u Pal'ack'i za Bur' atov ne vyxoz'iće 'in school the teachers forced us: why do you, Polish girls, do not marry Buryats?' - Pol. zastawiać (to block, to obstruct) achieved new meaning under the influence of Rus. homonymous заставлять 'to force'.

Derivational loan translations are also not numerous. According to J. Obara (1989: 194), they are new words coming into being with own morphemes as a copy of foreign model. 
p'otem zapðe c'one b'yło vśo 'after that everything was forbidden' - the new word zaprzecac inf. was created under the influence of Rus. запрещать (to forbid). The morpheme pr'e was replaced with its Pol. equivalents -pðe-. The new word has Polish conjugation.

J. Obara (1989: 204-209) defines phraseological loan translations as building idioms and phrases with own elements under the influence of the donor-language. This kind of loan translations is also rare.

$b^{\prime} y z^{\prime} e s^{\prime} w$ kol'asce inval'idnej j'eźż'ić 'you will drive the wheelchair' - the phrase kolaska inval'idna is a copy of Rus. phrase инвалидная коляска and was built up of Polish word kolaska in its broadened meaning and Russian adopted borrowing inval'idna.

More numerous are syntactic loan translations, i.e. copying of foreign language syntactic structures, government and word order (Obara 1989: 205-209).

b'yje na s'ev'er'e tam nap'ece L'ene 'he lives in the North, on Lena river' - instead of Polish nad rzeką Vershinians use a copy of Rus. syntactic model реке;

o ješčc'o do vojny, a z'adek ve v'ojne 'umart 'it was before the war, and the grandfather died during the war' - Pol. przed wojnq was replaced with a copy of Rus. войны;

to źinć, typ go ní ma $\boldsymbol{w} \boldsymbol{p y} \boldsymbol{y} \boldsymbol{v}^{\prime} \boldsymbol{y x}$ 'this is my son-in-law, he is also dead' - Pol. nie ýyje was replaced with a copy of Rus. живых.

\section{The contemporary period (after 1990)}

After the postwar phase, there is another period in Vershina's history - the present time, which started after perestroika and the collapse of the Soviet Union - in the early 1990s. Thanks to the political changes, nowadays the inhabitants of Vershina regained their minority rights. They can pray in their own church, learn Polish language in a local school and found cultural organisations. Legalisation of minority education gives potential for an important factor which can help to maintain the language and culture of Vershina. According to T. Skuttnab-Kangas (1977: 193) transmission of minority culture and identity in a foreign language is very difficult if not impossible. Thanks to perestroika the Vershinians 
achieved new possibilities for preserving their language and culture. However, during the years of sovietization and atheization, they almost completely lost their Catholicism, and their culture and customs became much more similar to other Siberian villages. Nowadays it is very difficult to divide cultural elements of Polish origin from these, which were modified during one-hundred-years' Vershina's history. There is no more Polish nor Silesian culture, but a Polish-Russian-Soviet-Buryat cultural hybrid.

Cultural changes strongly affect the language situation. There are still more heterogeneous marriages between Poles and Russians as well as between Poles and Buryats. The children from Polish-Russian and Polish-Buryat families become monolingual; they use Polish very rare, only as a school subject and in contacts with grandparents. Children and youth whose both parents are of Polish origin, still try to use the language of their ancestors and are motivated to learn it. However, they do not use it in peer groups even in their village.

\section{Changes of communicative situation}

If we compare the model of communicative situation in the pre-war period with the contemporary time, many important differences become visible. The postwar period is transitional and fluid - its early stage was more similar to the time before the Second World War, and the late - to the present time. In the pre-war period Polish was not only the language of communication between the migrants but also the code of interethnic communication in the village (see Tables A and B).

\begin{tabular}{|c|c|c|}
\hline \multicolumn{3}{|c|}{$\begin{array}{l}\text { A. Communication in Vershina among the descendants of Polish migrants in the pre } \\
\text { war period. }\end{array}$} \\
\hline Sender & receiver & code/codes of communication \\
\hline all generations & all generations & only Polish \\
\hline
\end{tabular}

\begin{tabular}{|c|c|c|}
\hline \multicolumn{3}{|c|}{$\begin{array}{l}\text { B. Communication in Vershina between Polish and other nationalities in the pre-wa } \\
\text { period. }\end{array}$} \\
\hline Sender & receiver & code/codes of communication \\
\hline Polish & Russian/Buryat & Polish and seldom Russian \\
\hline Russian/Buryat & Polish & Russian and Polish \\
\hline
\end{tabular}


Nowadays the communicative situation is completely different. Polish in interethnic contacts is used only by a few representatives of the older generation (see Table $\mathrm{C}$ ).

\begin{tabular}{|l|l|l|}
\hline C. Communication in Vershina between Polish and other nationalities nowadays. \\
\hline sender & receiver & code/codes of communication \\
\hline Polish & Russian/Buryat & $\begin{array}{l}\text { Russian and only in the old } \\
\text { generation sometimes Polish }\end{array}$ \\
\hline Russian/Buryat & Polish & only Russian \\
\hline
\end{tabular}

The code of communication between the descendants of Polish settlers depends on the generation of the sender and receiver. According to Table $\mathrm{D}$, the usage of Polish language is more possible among older interlocutors.

\begin{tabular}{|l|l|l|}
\hline \multicolumn{3}{|l|}{ D. Communication in Vershina among the descendants of Polish migrants nowadays. } \\
\hline sender & receiver & code/codes of communication \\
\hline old generation & old generation & $\underline{\text { Polish and seldom Russian }}$ \\
\hline old generation & middle-aged generation & $\underline{\text { Polish and Russian }}$ \\
\hline old generation & young generation & Polish and Russian \\
\hline middle-aged generation & old generation & Polish and Russian \\
\hline middle-aged generation & middle-aged generation & $\underline{\text { Russian and Polish }}$ \\
\hline middle-aged generation & young generation & $\underline{\text { Russian and seldom Polish }}$ \\
\hline young generation & old generation & $\underline{\text { Russian } \text { and seldom Polish }}$ \\
\hline young generation & middle-aged generation & $\underline{\underline{\text { Russian }}}$ \\
\hline young generation & young generation & $\underline{\text { Russian }}$ \\
\hline
\end{tabular}

\section{Is the language maintenance possible?}

The Tables $\mathrm{C}$ and $\mathrm{D}$ show that there are serious and sharp differences between the young and the old generations. Their generational sociolects differ not only in communicative aspect but also in other language levels. One has to admit that the language of the youth and of the oldest members of the community were developing in different social, economic and political conditions. Older people still use the language of their childhood. It contains many borrowings and syntactic loan translations but we can not consider it as a mixed language or a hybrid - it is still a Southern Polish dialect with its orthophony and structure. When Russian elements appear in their speech, we shall classify these cases not as unconscious codemixing, but code-switching (Muysken 2000: 4). We can observe changing of code inside a single utterance in the older generation's 
sociolect, but in most cases it is caused by the change of context or is used to contrast some term, i.e. it is metaphorical or situational (Auer 1989: 89-91). Speakers are able to recognize Polish as well as Russian elements in their speech in such situations.

On the opposite, Polish language of the young generation practically does not exist. It is reduced to the role of a school subject and for limited contacts with grandparents. In the young generation the language has very weak support from the filed of identity. The role of Polishness in the identity of young Vershinians is reduced to the consciousness of their origin and distinctness from Buryats and Russians.

Nowadays only the oldest Vershinians use Polish in their everyday communication, and it means that most of primary groups such as neighbourhood, peer groups and also families, speak predominantly Russian. The lack of Polish language in primary socialization brings to the language death. The process of forgetting mother tongue in Vershina is growing rapidly, while people who neither use Polish are not interested in the culture of Poland and tend to forget the language even in passive use - they don't understand it. Jeffrey Holdeman (2002: 14-15) from Ohio State university enumerates common examples of language death: reduction in complexity and diversity of structural features, reduction and adaptation of linguistic structures, "rule loss", stylistic shrinkage, reduction of registers, functional restrictions, perception of inferiority among speakers, shift of language of religion to majority language, shift to majority language in the home domain and bilingual parents passing on only one language to their children. Practically all of these signs have been recorded in Vershina's language situation. The role of religion is not of great importance now. Only about 20-30 of 400 Vershinians attend Sunday services. The liturgy is Polish, but after the service the priest summarizes the Gospel and sermon in Russian for young people who did not understand it.

However, there are some factors which may hinder the actual changes: the activity of local Polish organisations and also of Roman Catholic parish, which social influence is stronger than the religious one. On one hand, Polish community activists encourage the inhabitants of Vershina, especially children and youth, to learn Polish and to study in Poland. The church organisations also try to revitalise Polish language and culture in Siberia. There is also an active folk group "Jazhumbek" singing Polish traditional songs. On 
the other hand, if these activities do not engage a considerable number of Vershinians they will be only of symbolic importance.

\section{Summary}

Vershina was founded in 1910 by Polish voluntary settlers from North-Eastern Silesia and Little Poland. During its first three decades Vershina represented a piece of Poland in the heart of Siberia. The village preserved Polish language, traditions, farming methods and machines and also the Roman Catholic religion. Although the Revolution of 1917 meant the end of the former Russia with its economic system, the effects of changes came to a village in taiga only in the 1930s. As a result of collectivisation, the citizens of Vershina lost their farms which were annexed into a kolkhoz and the village lost its former ethnocultural homogeneity because of Russian and Buryat workers.

Nowadays the inhabitants of Vershina regained their minority rights: they can pray in their own church, learn Polish in a local school and found cultural organisations. However, during the years of sovietization and ateization, their culture and customs became much more similar to other Siberian villages.

Polish language in Vershina is under strong influence of Russian, which is the language of education, administration, and surrounding villages. There are still more heterogeneous marriages and the children from Polish-Russian families become monolingual; they use Polish very rare, only as a school subject and in contacts with grandparents. The language of family, peer and neighbourhood groups, strongly influences the developing idiolect. The process of forgetting mother tongue in Vershina is growing rapidly, while people who neither use Polish nor are interested in the culture of Poland tend to forget the language even in passive use they don't understand it. However, there are some factors which may hinder the actual changes: the activity of local Polish organisations and Roman Catholic parish as well as folk group "Jazhumbek".

\section{Address:}

Michał Głuszkowski

Ul. Bolesława Chrobrego 11/9

87-100 Toruń

Poland

E-mail: micglu@umk.pl 


\section{References}

Auer, P. (1984) "On the meaning of conversational code-switching”. In P. Aueret A. di Luzio., eds. Interpretive Sociolinguistics, 87-112. Tübingen: Günther Narr Verlag.

Bazylow, L. (1975) Syberia. Warszawa: Wiedza Powszechna.

Berger, P. and T. Luckmann (1983) Społeczne tworzenie rzeczywistoúci. Warszawa: PWN.

Cooley, Ch. (1992) “Grupy pierwotne”. In Mucha J. Cooley 209-214. Warszawa: Wiedza Powszechna.

Dybowski, B. (2007) “Z wizytą u Buriatów”. In A. Kuczyński, ed. Syberia. 400 lat polskiej diaspory. Zesùania, martyrologia i sukces cywilizacyjny Polaków, 224-246. Krzeszowice: Kubajak.

Ferguson, Ch. (1959) "Diglossia". Word 15, 325-340.

Figura, L. (2003) “Historia i teraźniejszość polskiej syberyjskiej wsi”. In E. Nowicka and M. Głowacka-Grajper, eds. Wierszyna z bliska i z oddali. Obrazy polskiej wsi na Syberii, 71-132. Warszawa: Nomos.

Grek-Pabisowa, I. (1999) “Typy zapożyczeń i sposoby przyswajania wyrazów polskich”. In I. Grek-Pabisowa Staroobrzędowcy. Szkice z historii, języka, obyczajów, 211-227. Warszawa: SOW.

Holdeman, J. (2002) Language maintenance and shift among the Russian Old Believers of Erie, Pennsylvania. Ohio: Ohio State University (unpublished $\mathrm{PhD}$ dissertation).

Muysken, P. (2000) Bilingual speech: a typology of code mixing. Cambridge: Cambridge University Press.

Nowicka, E. and M. Głowacka-Grajper (2003)“ Polskoúã zastygùa. Spojrzenie antropologa na Wierszynæ”. In E. Nowicka and M. Głowacka-Grajper Wierszyna z bliska i z oddali. Obrazy polskiej wsi na Syberii, 33-70. Warszawa: Nomos.

Obara, J. (1989) “Kalki jako jeden z przejawów interferencji językowej”. In S. Warchoł, ed. Interferencje językowe na różnych obszarach Słowiańszczyzny, 185-210. Lublin: UMCS.

Skuttnab-Kangas, T. (1977) "Language in the process of cultural assimilation and structural incorporation of linguistic minorities". In C.-Ch. Elert, S. Ellasson, S. Fries, and S. Ureland, eds. Dialectology and sociolinguistics. Essays in honour of Karl-Hampus Dahlstedt, 191-203. Umea: Acta Universitatis Umensis.

Szostak, J. (2002) “Epitafium pomordowanym przez NKWD mieszkańcom polskiej wsi Wierszyna we Wschodniej Syberii koło Irkucka w 1938 roku”. Rocznik Historyczny Muzeum Polskiego Ruchu Ludowego 18, 221-236.

Wiśniewska, A. (2000) "Proces kształtowania się i rozwoju tożsamości etnicznej mieszkańców Wierszyny (Syberia środkowa)". Etnografia Polska 44, $1-2,99-114$. 
Адамовичюте-Чекмонене, И. (2003) “К характеристике польсколитовского билингвизма поляков Йонавского района Литвы”. In A. Engelking and R. Huszcza, eds. Pogranicza jêzyków, pogranicza kultur, 139-148. Warszawa: Wydział Polonistyki UW.

Гольцекер, Ю. (1989) “Из наблюдений над особенностями польского говора села Вершина в Сибири”. In S. Warchoł ed. Interferencje jêzykowe na różnych obszarach Słowiańszczyzny, 133-147. Lublin: UMCS.

Дуличенко, А. (1998) “Языки малых этнических групп: статус, развитие, проблемы выживания”. In А. Дуличенко, ed. Языки малье и большие... In memoriam acad. Nikita L. Tolstoi, 26-36. (Slavica Tartuensia, 4.) Tartu: Universitas Tartuensis.

Петшик, В. (2008) Маленькая Польша в таежной Сибири. Норильск: Апекс.

Kokkuvõte. Michal Gluszkowski: Veršina - Poola küla Siberis. Tegurid, mis mõjutavad keele säilimist sotsiaalsete, kultuuriliste, majanduslike ja poliitiliste tingimuste muutuvas olukorras. Artikkel käsitleb tegureid, mis mõjutavad Siberis elava poola rahvusvähemuse keele säilimist muutuvates sotsiaalsetes, kultuurilistes, majanduslikes ja poliitilistes tingimustes. Veršina küla asutasid Väike-Poolast pärit poolakatest vabatahtlikud ümberasujad 1910. aastal. Kolme esimese aastakümne jooksul säilis Veršinas poola keel, traditsioonid, tootmisviis ja masinad, säilis isegi rooma-katoliku usk. Muutused algasid selles taigakülas 1930ndatel, kui Veršina kaotas oma etnokultuurilise homogeensuse kohaliku kolhoosi vene ja burjaadi tööliste tõttu. Praeguseks on Veršina elanikud taastanud oma vähemuste õigused: religioossed, hariduslikud ja kultuurilised. Siiski on nende kultuur ja kombed nõukogustamise ja ateismiaastatel muutunud sarnasemaks teiste Siberi küladega. Veršinas on poola keel tugevate vene keele mõjudega. Vene keel on haridus- ja administratiivkeel ning ümberkaudsete külade keel. Poola-vene perede lapsed on muutunud ükskeelseteks ja kasutavad poola keelt väga harva: vaid õppeainena koolis ja suhtlemisel oma vanavanematega. Veršinas kulgeb emakeele hülgamise protsess kiiresti kasvanud. Siiski on mõned tegurid, mis võivad takistada tegelikke muutusi: kohalike Poola organisatsioonide tegevus, rooma-katoliku kogudus, rahvusrühmitus Jazhumbek.

Märksõnad: kakskeelsus, keele säilitamine, keelesurm, poolakad, Siber 